Long, J. E., \& Link, A. N. (January 01, 1983). The impact of market structure on wages, fringe benefits, and turnover. Industrial and Labor Relations Review, 36, 2, $239-250$.

Made available courtesy of Cornell University:

http://digitalcommons.ilr.cornell.edu/ilrreview/

$\star \star \star$ Reprinted with permission. No further reproduction is authorized without written permission from Cornell University.

\title{
THE IMPACT OF MARKET STRUCTURE ON WAGES, FRINGE BENEFITS, AND TURNOVER
}

\author{
JAMES E. LONG and ALBERT N. LINK*
}

\begin{abstract}
This paper examines the relationship between labor compensation and the structure of the product market, which is measured by the industry concentration ratio and by dummy variables for the existence and type of government regulation. Unlike previous studies that have estimated the impact of concentration and regulation on wages or earnings, this study extends the analysis to include the effect of market structure on employer-provided pensions and insurance and on voluntary labor turnover. The hypothesis that product market power raises labor compensation is supported by empirical results indicating that concentration increases wages and fringes but lowers voluntary labor turnover. Regulations that set minimum prices and restrict entry raise labor compensation, since wage premiums due to regulation are not offset by lower pensions and insurance or higher turnover. Other forms of regulation, such as profit regulation in public utilities, are found to reduce labor compensation, as evidenced by higher turnover or lower wages and fringes, or both.
\end{abstract}

A LARGE number of studies have examined the impact of product market structure on labor earnings. It has been suggested that firms with market power pay relatively higher wages because (1) workers in concentrated industries capture part of the monopoly profits, (2) labor costs in concentrated industries can be more easily passed on to consumers, and (3) the small number of firms in concentrated industries makes it easier for unions to organize and raise wages. Empirical evidence on the relationship between concentration and

* James Long is an associate professor of economics at Auburn University and Albert Link is a professor of economics at the University of North Carolina at Greensboro. wages is mixed, however. Weiss, Masters, Haworth and Rasmussen, Ashenfelter and Johnson, and Hendricks find that concentration has no statistically significant effect on wages once industrial characteristics and employee quality are held constant. ${ }^{1}$ In contrast, Dalton and Ford esti-

\footnotetext{
'Leonard Weiss, "Concentration and Labor Earn. ings," American Economic Review, Vol. 56, No. 1 (March 1966), pp. 96- 117; Stanley H. Masters, "Wages and Plant Size: An Interindustry Analysis," Review of Economics and Statistics, Vol. 51, No. 3 (August 1969), pp. 341-45; Charles T. Haworth and David W. Rasmussen, "Human Capital and Inter-Industry Wages in Manufacturing," Review of Economics and Statistics, Vol. 53, No. 4 (November 1971), pp. 376-80; Orley Ashenfelter and George E. Johnson, "Unionism, Relative Wages and Labor Quality in U.S. Manufacturing Industries," International Economic Re-
} 
mate that firms in concentrated industries pay higher wages than competitive firms, a relationship Haworth and Reuther find occurring only during cyclical periods of slack demand and stable prices. ${ }^{2}$ In summarizing the effects of market structure on wages, Hendricks points out that the estimated effect of concentration depends on the control variables and samples used and on the occupations and time periods examined. $^{3}$

To the extent that government regulation can affect the pricing policies and structure of industries, product market regulation is another potential influence on labor earnings. For example, by limiting the entry of firms into the market, regulation may reduce competition and enable unions to raise wages above the level that would have existed in the absence of regulation. The resistance of firms to demands for higher wages may be increased, however, by regulations that set maximum prices to insure minimum profits. Hendricks investigates the effect of regulation on earnings and finds that annual earnings are lower in regulated industries than in unregulated manufacturing, a result that is consistent with Weiss's findings. ${ }^{4}$ Nevertheless, labor earnings are relatively higher in industries in which regulatory authorities set minimum prices and restrict entry, as in trucking and airlines. ${ }^{5}$ Also, Ehrenberg

view, Vol. 13, No. 3 (October 1972), pp. 488-50̄; and Wallace Hendricks, "Regulation and Labor Earnings," Bell Journal of Economics, Vol. 8, No. 2 (Autumn 1977), pp. 483-96.

2James A. Dalton and E. J. Ford, "Concentration and Labor Eamings in Manufacturing and Utilities," Industrial and Labor Relations Review, Vol. 31, No. 1 (October 1977), pp. 45-60, and James A. Dalton and E. J. Ford, "Concentration and Professional Earnings in Manufacturing," Industrial and Labor Relations Review, Vol. 31, No. 3 (April 1978), pp. 379-84; Charles T. Haworth and Carol Jean Reuther, "Industrial Concentration and Interindustry Wage Determination," Review of Economics and Statistics, Vol. 60, No. 1 (February 1978), pp. 85-95.

${ }^{8}$ Wallace Hendricks, "Unionism, Oligopoly, and Rigid Wages," Review of Economics and Statistics, Vol. 63, No. 2 (May 1981), pp. 198- 205.

"Hendricks, "Regulation and Labor Earnings," and Weiss, "Concentration and Labor Earnings.'

"See, for example, Hendricks, "Regulation and Labor Earnings," and Thomas G. Moore, "The Beneficiaries of Trucking Regulation," Journal of Law and estimates that telephone industry employees in New York have substantially higher earnings than other comparable employees in the state. ${ }^{6}$

These studies differ in the data bases, variable definitions, and time periods used, which complicates any direct comparison of their results. Yet, one factor is common to all these studies: they have focused almost exclusively on wages or nominal earnings. None, that is, directly considers the influence of market structure on nonwage compensation such as fringe benefits. Employer contributions to employee pension and insurance plans have grown rapidly in recent years and now average close to 10 percent of wages and salaries; in large manufacturing firms, the percentage is much higher. ${ }^{7}$ Ideally, for estimating the social costs of market imperfections, one would want to know the impact of concentration and regulation on the total (wage plus nonwage) compensation of workers.

Three empirical issues are therefore considered in this paper. First, we examine the impact of market structure on wage levels, using a data base that has some important advantages over those used in previous studies. Second, we analyze the relationship among concentration, regulation, and employer expenditures on private pension and insurance funds. And finally, we estimate the effect of market structure on labor turnover, holding constant the influence of concentration and regulation on wage rates.

\section{Market Structure and Wages}

Inadequate control for worker "quality" can bias the regression estimates of the net

Economics, Vol. 21, No. 2(October 1978), pp. 327-44

${ }^{6}$ Ronald G. Ehrenberg, The Regulatory Process and Labor Earnings (New York: Academic Press, 1979), pp. $69-90$.

${ }^{7}$ For evidence, see James E. Long and Frank A. Scott, "The Income Tax and Nonwage Compensation," Review of Economics and Statistics, Vol. 64, No. 2 (May 1982), pp. 211-19. The 10 percent figure applies to voluntary rather than legally required employer contributions, such as OASDHI. For a survey of employee fringe benefits by industry, see Chamber of Commerce of the United States, Employee Benefits 1980 (Washington, D.C.: Chamber of Commerce, 1981). 
impact of market structure on wages. For this reason, National Longitudinal Survey (NLS) data have some desirable properties for wage analyses. First, the NLS contains data on actual firm-specific work experience and prior employment history, along with other important productivity controls such as educational attainment, duration of job training, and health status. Second, the NLS reports individuals' hourly wage rates, which can be used as dependent variables in wage equations. Other studies have resorted to industry averages or have proxied individual wage rates with annual earnings standardized for time worked. ${ }^{8}$ Of course, the NLS data are not without drawbacks, namely, the small sample sizes and narrow age ranges.

We have taken the NLS sample of mature males (aged forty-five to fifty-nine in 1966) and estimated wage equations with the natural logarithm of the hourly wage in 1966 as the dependent variable. The independent variables are years of work experience with the current employer, EXP; experience squared, $E X P^{2}$; years of formal schooling, $E D U C$; months of job-related training, TRAIN; a dummy variable equal to one if health limits working and equal to zero if otherwise, $H L T H$; a dummy variable equal to one if married with spouse present and zero if otherwise, MSP; a dummy variable equal to one if white and zero if otherwise, WHITE; dummy variables for region, SOUTH and WEST; the percent of workers in the industry covered by collective bargaining, $U ; 9$ the percent of the industry that

${ }^{8}$ Researchers using the tapes from the 1970 Census 1-1000 Public Use Sample measure annual hours worked as the product of current weekly hours of work and weeks worked for the prior year (with both hours and weeks measured as intervals), a practice that may bias estimates of the hourly wage rate.

${ }^{9}$ The unionization figures refer to the percent of all production workers in the industry covered by collective bargaining during the period 1968-72, as estimated from the Expenditures for Employee Compensation Survey administered by the U.S. Bureau of Labor Statistics. These data can be found in Richard B. Freeman and James L. Medoff, "New Estimates of Private Sector Unionism in the United States," Industrial and Labor Relations Review, Vol. 32, No. 2(January 1979), pp. 143- 74 .

Ideally, we would like to have information on the union status of each individual in the sample, but is employed in plants having 500 or more employees, LGFIRM; the industry concentration ratio, $C ;^{10}$ the interaction between unionization and concentration, $U \cdot C$; and dummy variables for regulated industries, REG, MAX, MIN, and VAR."11 Our sample is restricted to 1,514 wage and salary employees in private, regulated industries and unregulated manufacturing. The regression results appear in Table 1.

The basic earnings model, Equation 1 , explains over 40 percent of the variation in 1966 wages; and all of the control variables for employee and industry characteristics are statistically significant with the expected signs. The coefficients of $C$ and $U \cdot C$ are highly significant and their signs indicate that concentration raises wages although its impact diminishes with unionization. ${ }^{12} \mathrm{~A}$ unit increase in concentration raises wages by $.345, .245, .145$, and .045 percent at unionization levels of $20,40,60$, and 80 percent, respectively. ${ }^{13}$ Thus, at a

such information is not provided in the census data used by Weiss and Hendricks or in the NLS data for the year 1966. Such data are available in the 1971 NLS, however, and we have compared the wage equation parameters when the industry level of unionization is replaced by a dummy variable for union membership (more correctly, coverage of the individual by a collective bargaining contract). These results indicate that the coefficients of the concentration and regulation variables do not vary with the measure of unionization.

${ }^{10}$ Concentration estimates for the industry categories in the NLS sample were kindly provided by Wallace Hendricks.

"MAX denotes industries in which maximum prices are regulated (telephone, electricity, gas and steam, water); $M I N$ denotes industries in which minimum prices are regulated and also entry is restricted (air transportation, trucking); and $V A R$ denotes all other regulated industries (railroad, bus, taxicab, warehousing, water transportation, services incidental to transportation, radio and television, and sanitary). $R E G$ includes all of these regulated industries. See Hendricks, "Regulation and Labor Earnings," pp. $485-87$, for a discussion of the primary regulatory authority and its powers in various industries.

${ }^{12} \mathrm{~A}$ negative relationship between wages and $U \bullet C$ was also found by Weiss, "Concentration and Labor Earnings"; Frederic M. Sherer, Industrial Market Structure and Economic Performance, 2d ed. (Chicago: Rand McNally, 1980), p. 359; and Hendricks, "Unionism, Oligopoly, and Rigid Wages."

${ }^{13}$ These estimates are obtained by evaluating the expression

$\partial W A G E / \partial \mathrm{C}=.00445-.00005 U$. 
Table 1. Regression Analyses of the Effect of Concentration and Regulation on Wage Rates, 1966.

( $t$-values in parentheses)

\begin{tabular}{|c|c|c|}
\hline Variables & Equation 1 & Equation 2 \\
\hline $\mathrm{C}$ & $\begin{array}{l}.00445^{* *} \\
(3.06)\end{array}$ & $\begin{array}{l}.00492^{* *} \\
(3.42)\end{array}$ \\
\hline $\mathrm{U} \cdot \mathrm{C}$ & $\begin{array}{l}-.00005 * \\
(-2.41)\end{array}$ & $\begin{array}{l}-.00003 \\
(-1.72)\end{array}$ \\
\hline REG & $\begin{array}{l}-.01804 \\
(-.60)\end{array}$ & - \\
\hline MAX & - & $\begin{array}{l}-.00211 \\
(-.04)\end{array}$ \\
\hline MIN & - & $\begin{array}{l}.14863^{* *} \\
(3.24)\end{array}$ \\
\hline VAR & - & $\begin{array}{l}-.16692^{* *} \\
(-4.27)\end{array}$ \\
\hline $\mathrm{U}$ & $\begin{array}{l}.00436^{* *} \\
(3.39)\end{array}$ & $\begin{array}{l}.00349^{* *} \\
(2.62)\end{array}$ \\
\hline LGFIRM & $\begin{array}{l}.33277^{*} \\
(2.36)\end{array}$ & $\begin{array}{l}.2393 \\
(1.71)\end{array}$ \\
\hline EXP & $\begin{array}{l}.01216^{* *} \\
(4.72)\end{array}$ & $\begin{array}{l}.01197 * * \\
(4.69)\end{array}$ \\
\hline $\operatorname{EXP}^{2}$ & $\begin{array}{l}-.00012 \\
(-1.78)\end{array}$ & $\begin{array}{l}-.00011 \\
(-1.57)\end{array}$ \\
\hline MSP & $\underbrace{.09119 * *}_{(2.92)}$ & $\begin{array}{l}.09882^{* *} \\
(3.19)\end{array}$ \\
\hline EDUC & $\begin{array}{l}.04275^{* *} \\
(14.72)\end{array}$ & $\begin{array}{l}.04156^{* *} \\
(14.45)\end{array}$ \\
\hline TRAIN & $\begin{array}{l}.00204^{* *} \\
(3.50)\end{array}$ & ${ }_{(3.62)}^{.00208^{* *}}$ \\
\hline SOUTH & $\begin{array}{l}-.14971 * * \\
(-6.89)\end{array}$ & ${ }^{-.14113^{* *}}$ \\
\hline WEST & $\begin{array}{l}.14187^{* *} \\
(5.25)\end{array}$ & $\begin{array}{l}.14673^{* *} \\
(5.49)\end{array}$ \\
\hline WHITE & $\begin{array}{l}.15275^{* *} \\
(6.90)\end{array}$ & $\underbrace{.14882 * *}_{(6.77)}$ \\
\hline Constant & $\begin{array}{l}4.57168^{* *} \\
(50.50)\end{array}$ & $\begin{array}{l}4.57487 * * \\
(50.86)\end{array}$ \\
\hline $\mathbf{R}^{2}$ & .4250 & .4395 \\
\hline F-level & 85.52 & 78.29 \\
\hline $\mathbf{N}$ & 1514 & 1514 \\
\hline
\end{tabular}

* Significant at the .05 level in a two-tailed test.

**Significant at the .01 level in a two-tailed test. unionization level of 70 percent (the sample mean), wages in high-concentration industries ( $C$ equals 70 percent) are 4.75 percent higher than wages in low-concentration industries ( $C$ equals 20 percent). In contrast, the wage differential between high-unionization ( $U$ equals 70 percent) and lowunionization industries $(U$ equals 20 percent) is 8.8 percent at the mean concentration level of 52 percent.

In Equation 2, the single dummy variable for industry regulation ( $R E G)$ is replaced by separate variables for the specific type of regulation $(M A X, M I N$, and $V A R)$. The estimated coefficients of the concentration terms now imply a much larger impact of market power on wages-about a 14 percent wage differential between high- and lowconcentration industries. Controlling for the specific type of industry regulation is thus important in estimating the net impact of concentration on wages, as well as in estimating the union wage effect (which increases to 9.6 percent in Equation 2).

The finding that concentration raises wages is very robust and does not depend on cyclical factors such as high unemployment and stable prices, as suggested by Haworth and Reuther, or on concentration's being less than some critical value, as estimated by Dalton and Ford. ${ }^{14}$ This conclusion (as well as those of previous studies) should be tempered, however, by the recognized weaknesses of concentration ratios, including the fact that the industry definitions used in their measurement are arbitrary and do not necessarily conform

\footnotetext{
${ }^{14}$ Haworth and Reuther, in "Industrial Concentration and Interindustry Wage Determination," find the concentration impact on wages to be positive and significant only during a recessionary period. The year 1966 was one of low unemployment (2.9 percent). When our wage equations were estimated with NLS data for 1971, a year of high unemployment (5.0 percent), the impacts of high concentration and $M I N$ regulation on wages were similar to those reported in Table $I$ and equally significant.

Dalton and Ford, in "Concentration and Labor Earnings," estimate that increases in concentration above the 50 percent level do not affect manufacturing wages. We find that estimating the wage equations with concentration-squared terms leaves the estimated wage differentials between high- and low. concentration industries virtually unchanged.
} 
to economic markets and also the fact that no information is provided about the market shares of individual firms.

The estimated coefficient of REG in Equation 1 is not statistically different from zero, which indicates that wages do not differ between regulated industries and unregulated manufacturing, once human capital, location, and industry characteristics are held constant. The estimates in Equation 2 substantiate Hendricks's hypothesis that a single dummy variable misrepresents the wage impact of industry regulation. ${ }^{15}$ Regulation has no effect, for example, on wages in utility industries in which maximum prices $(M A X)$ are set and entry is restricted, such as the telephone, electricity, gas and steam, and water industries. This finding suggests that the impact on labor costs of "cost price-through" utility pricing schemes is offset by the inflexibility of rate changes due to regulatory lags. ${ }^{16}$

Setting minimum prices $(M I N)$ and controlling entry into the market, on the other hand, raises wages by about 15 percent, suggesting that union power in air transportation and trucking is increased by regulations that reduce competition from nonunion labor. Finally, wages are nearly 17 percent lower in railroads, local passenger transit, warehousing, radio and television, and other industries in which regulatory practices are more varied $(V A R)$ and have not altered market structure and pricing policies in ways that might increase union power.

Assigning the degree and type of regulation to an industry also involves some arbitrary judgments that qualify the inferences drawn from the coefficients of the regulation variables. In addition, a problem in interpreting the coefficient of $M I N$ is that air transportation and trucking are industries characterized by spatial production limitations that act to curb the entry of new firms outside the union's jurisdiction. In long-line trucking, for example, a union firmly established in a few key cities within

\footnotetext{
${ }^{15}$ Hendricks, "Regulation and Labor Earnings."

${ }^{16}$ For additional discussion, see Ehrenberg, The Regulatory Process and Labor Earnings, pp. 11- 12.
}

a region will be protected from nonunion competition because new entrants must almost always operate in the same key cities. Levinson argues that these spatial limitations of production, rather than the control of entry by regulatory authorities, are responsible for the Teamsters' success in raising wages. ${ }^{17}$

In this paper, we are unable to determine which entry barrier-spatial production limitations or regulation-is more important in raising wages in air transportation and trucking. ${ }^{18}$ Nonetheless, we believe it is important to include the regulation variables in the wage equation, if for no other reason than to serve as controls for estimating the wage impact of concentration.

Since the earnings model includes a number of control variables for worker quality and industry characteristics, the findings in Table 1 suggest that employees in highconcentration and $M I N$-regulation industries receive economic rent in the form of wage premiums. The correct measure for determining whether workers receive economic rent, however, is total labor compensation, which equals wages and salaries plus such nonwage compensation as employer-provided fringe benefits (pensions and health insurance), job satisfaction, and employment stability. The impact of market structure on nonwage compensation is

${ }^{17}$ Harold M. Levinson, "Unionism, Concentration, and Wage Changes: Toward A Unified Theory," Industrial and Labor Relations Review, Vol. 20, No. 2 (January 1967), pp. 198-205.

${ }^{18}$ Both theory and empirical evidence suggest that the latter effect may dominate. Moore, "The Beneficiaries of Trucking Regulation," argues that the operating-ratio regulation in trucking tends to increase labor costs, aside from any additional union strength due to reduced competition from nonunion drivers. Empirically, the annual growth in hourly earnings in trucking has slowed considerably since 1977 , relative to earnings growth during earlier years and relative to manufacturing wage increases since 1977. Entry into trucking has been less restricted since 1977, particularly for short-haul carriers, and deregulation policies have been gaining support. Since there is little reason to expect that spatial production limitations have changed radically since 1977 , the relatively slower wage growth in trucking may reflect the influence of greater competition. 
examined in the following sections of the paper.

\section{Market Structure and Fringe Benefits}

Data on one form of nonwage compensation-voluntary employer contributions for pension and profit-sharing plans and for group health and life insurance-can be derived from U.S. Department of Commerce estimates of employee compensation by industry. ${ }^{19}$ In estimating the relationship between market structure and employer expenditures on these fringe benefits, it is important to control for those determinants of fringe benefits that correlate with concentration and regulation. The variables expected to affect fringes have already been discussed in detail elsewhere, so only a brief description of the model is presented here. ${ }^{20}$

Fringe benefits should vary positively with total employee compensation because of the positive income elasticity of demand for fringes and the positive tax-rate elasticity that results from the preferential tax treatment of fringe benefits. ${ }^{21}$ Unionization is thought to have a positive effect on fringe benefits, since union leaders can inform their members of the tax advantages of fringe benefits and of the cost savings of group insurance and since employee prefer-

${ }^{19}$ U.S. Department of Commerce, Survey of Current Business, Vol. 59, No. 7 (July 1979), pp. 54-55. Voluntary employer contributions for pensions and insurance were estimated by first subtracting wages and salaries from total employee compensation and then subtracting the legally required employer contributions to OASDHI. OASDHI payments by industry were calculated as $(.0605)(W A G E)(F T E)$ for WAGE > $\$ 17,700$ or $(\$ 1,071)(F T E)$ for $W A G E \leq \$ 17,700$, where $W A G E$ is average annual wage and salary earnings per full-time employee and FTE is total industry full-time employment.

${ }^{20}$ See Robert G. Rice, "Skill, Earnings, and the Growth of Wage Supplements," American Economic Review, Vol. 56, No. 2 (May 1966), pp. 583-93; Bevars Mabry, "The Economics of Fringe Benefits," Industrial Relations, Vol. 12, No. 1 (February 1973), pp. 95-106; Richard B. Freeman, "The Effect of Unionism on Fringe Benefits," Industrial and Labor Relations Review, Vol. 34, No. 4 (July 1981), pp. 489-509; and Long and Scott, "The Income Tax and Nonwage Compensation."

${ }^{21}$ See John S. Nolan, "Taxation of Fringe Benefits," National Tax Journal, Vol. 33, No. 3 (September 1977), pp. $359-68$. ences for fringe benefits can be directly transmitted to management by collective bargaining. Because of rate differentials between group and individual health or life insurance policies, fringe benefits should vary directly with firm size, assuming the demand for group insurance is price-elastic. Employers may have a preference for certain types of fringe benefits that reduce labor turnover, such as nonvesting pension plans or paid vacations whose length increases with tenure. These kinds of fringe benefits are most likely to be offered when turnover costs are high, which is the case if much of employees' human capital is firm-specific.

The impact of concentration and regulation on fringe benefits is obtained by estimating the equation:

$$
F B_{i}=a+b C_{i}+c R_{i}+d X_{i},
$$

where $F B_{i}$ is annual voluntary employer expenditures in 1978 on pensions, profit sharing, and insurance, measured as dollars per full-time employee; $C_{i}$ is the industry concentration ratio; $R_{i}$ consists of dummy variables indicating the existence and type of regulation, as defined earlier; and the vector $X_{i}$ includes the control variables TOTCOMP (average annual total compensation per employee), FIRMSZ (average firm size), KLRATIO (the ratio of capital to labor), $U$ (the percent of industry employees covered by collective bargaining), and $U \cdot C$ (an interaction between unionization and concentration). Data for these variables are available for twenty-eight two- and threedigit industries, which include manufacturing, transportation, communication, and public utilities. ${ }^{22}$ The ordinary least

\footnotetext{
${ }^{22}$ Concentration ratios for two-digit manufacturing industries came from William G. Shepherd, The Economics of Industrial Organization (Englewood Cliffs, N.J.: Prentice-Hall, 1979), p. 202. Concentration data for regulated industries were provided by Wallace Hendricks. For two industries (local and inter-urban passenger transit and trucking and warehousing), it was necessary to average his data for census industries (using industry employment as weights) to match the Department of Commerce industry definitions. Average firm size was measured as the number of employees per establishment in 1977, as reported in the U.S. Bureau of Census, County Business Patterns 1977, United States Summary, CBP-79-1
} 
square estimates of the model are reported in Table $2 .{ }^{23}$

Table 2. Regression Analyses of the Effect of Concentration and Regulation on Employer Contributions for Pensions and Group Insurance, 1978.

( $t$-values in parentheses)

\begin{tabular}{|c|c|c|}
\hline Variables & Equation 1 & Equation 2 \\
\hline C & $\begin{array}{l}-31.189^{*} \\
(-2.55)\end{array}$ & $\begin{array}{l}-19.804 \\
(-1.48)\end{array}$ \\
\hline $\mathrm{U} \cdot \mathrm{C}$ & $\begin{array}{l}.854^{* *} \\
(3.90)\end{array}$ & $\begin{array}{c}.653^{*} \\
(2.64)\end{array}$ \\
\hline REG & $\begin{array}{r}-626.523 \\
(-1.67)\end{array}$ & - \\
\hline MAX & - & $\begin{array}{r}-230.861 \\
(-.37)\end{array}$ \\
\hline MIN & - & $\begin{array}{r}-401.641 \\
(-1.03)\end{array}$ \\
\hline VAR & - & $\begin{array}{c}-986.703^{*} \\
(-2.09)\end{array}$ \\
\hline $\mathrm{U}$ & $\begin{array}{c}-11.516 \\
(-.81)\end{array}$ & $\begin{array}{l}-.086 \\
(-.01)\end{array}$ \\
\hline ТОТСОМР & $\begin{array}{c}.085^{*} \\
(2.44)\end{array}$ & $\begin{array}{r}.072 \\
(1.99)\end{array}$ \\
\hline FIRMSZ & $\begin{array}{r}4.205 \\
(1.92)\end{array}$ & $\begin{array}{r}3.904 \\
(1.75)\end{array}$ \\
\hline KLRATIO & $\begin{array}{c}129.576^{* * *} \\
(5.72)\end{array}$ & $\begin{array}{l}124.217^{* *} \\
(5.24)\end{array}$ \\
\hline Constant & $\begin{array}{r}317.782 \\
(.51)\end{array}$ & $\begin{array}{c}21.618 \\
(.03)\end{array}$ \\
\hline $\mathbf{R}^{2}$ & .936 & .946 \\
\hline F-level & 41.51 & 35.26 \\
\hline $\mathbf{N}$ & 28 & 28 \\
\hline
\end{tabular}

* Significant at the .05 level in a two-tailed test. **Significant at the .01 level in a two-tailed test.

(Washington, D.C.: GPO, 1979), pp. 1-2. TOT COMP and KLRATIO (which is proxied by the ratio of corporate capital consumption allowances to industry employment) came from the U.S. Department of Commerce, Survey of Current Business, Vol. 59, No. 7 (July 1979), pp. 54, 55, and 60. Unionization data are from Freeman and Medoff, "New Estimates of Private Sector Unionism in the United States."

${ }^{23}$ Freeman, in "The Effect of Unionism on Fringe Benefits," p. 498, has pointed out that Equation
The concentration terms are highly sig. nificant in Equation 1, which includes only the single regulation variable. The coefficients of $C$ and $U \cdot C$ indicate that product market power raises fringe benefits, once unionization exceeds 37 percent. $^{24}$ The marginal effects of concentration on fringe benefits are $-14,+3,+20$, and +37 dollars at unionization levels of 20,40,60, and 80 percent, respectively. At a unionization level of 44 percent (the sample mean), therefore, pension and insurance contributions are $\$ 320$ higher in high-concentration ( $C$ equals 70 percent) than in low-concentration ( $C$ equals 20 percent) industries. When the three regulation variables are included in place of $R E G$, as in Equation 2, the absolute values of the concentration coefficients are diminished; but the $U \cdot C$ term, however, remains positive and highly significant. The estimates indicate that market power raises fringe benefits at unionization levels above 31 percent; at the mean level, employer contributions for pensions and insurance are $\$ 425$ higher in high- than in low-concentration industries. The impact of concentration on fringe benefits is thus much smaller than the $\$ 1,575$ effect due to unionization. ${ }^{25}$

1 is subject to simultaneity bias since TOTCOMP includes voluntary employer concributions for fringe benefits along with wages and salaries plus legally required supplements. Correcting for this problem, as he suggests, does not appreciably change our estimates of the impact of concentration and regulation on fringe benefits. Consequently, the corrected estimates are not reported in the text.

${ }^{24}$ Note that the positive and significant coefficient of $U \bullet C$ in Table 2 contrasts with that observed in Table I and in other wage studies. Together, these results indicate that in highly concentrated industries, increased unionization raises the share of total compensation allocated to fringe benefits-a finding consistent with the theory and evidence presented by Freeman, "The Effect of Unionism on Fringe Benefits." The tax savings from fringe benefits increase with concentration; and unions can inform members of the advantages of fringes and make worker preferences concerning the compensation mix known to management.

${ }^{25}$ This estimate assumes a concentration level of 49 percent (the sample mean) and a unionization differential of 50 percent (for example, $U$ equals 70 percent relative to $U$ equals 20 percent). 
When measured by a single variable, industry regulation reduces fringe benefits by $\$ 627$, although the statistical significance of $R E G$ is marginal. Equation 2 suggests that the negative effect of regulation on fringes should not be attributed to all types of regulation. Pension and insurance contributions are relatively lower (by $\$ 987$ ) only under $V A R$-type regulation, in which authorities do not consistently restrict entry or set minimum and maximum prices.

We know of no previous studies that have related fringe benefit expenditures to concentration and regulation; consequently, there are no benchmarks against which our estimates can be compared. Moreover, since we use aggregate industry data, our conclusions should be regarded as tentative. In the next section we propose an alternative test to determine the influence of concentration and regulation on nonwage compensation.

\section{Market Structure and Labor Turnover}

An alternative method for estimating the effect of market structure on nonwage compensation is derived from the assumption that, other things equal, individuals will quit their present jobs if they perceive that an alternative job offers a net advantage. If concentration or regulation generates positive (negative) economic rent in terms of higher (lower) wage or nonwage returns, workers in concentrated or regulated industries will therefore be less (more) likely to quit and move to other jobs than workers in competitive industries. Interindustry turnover differentials not resulting from wage differences among concentrated, regulated, and competitive industries can thus be assumed to result from differences in nonwage compensation. ${ }^{26}$

${ }^{26} \mathrm{~A}$ number of recent studies have used turnover data to analyze nonwage differentials by race and union status. For example, see Duane E. Leigh, "Unions and Nonwage Racial Discrimination," Industrial and Labor Relations Review, Vol. 32, No. 4 (July 1979), pp. 439-50; and Richard B. Freeman, "The Effects of Unionism on Worker Attachment to Firms," Journal of Labor Research, Vol. 1, No. 1 (Spring 1980), pp. 29-62. James E. Long has used quit behavior to estimate whether government workers
The impact of market structure on labor turnover has not been extensively researched. Hendricks indicates that regulated industries offer more stable employment than manufacturing, and Ehrenberg reports that quit rates are much lower for New York Telephone employees than for workers in manufacturing industries. Nevertheless, neither conclusion is supported by multivariate analysis that controls for nonregulation variables that influence turnover. ${ }^{27}$

Other empirical studies have found a significant, negative relationship between concentration and the industry's average annual quit rate. Burton and Parker suggest that quits are inversely related to concentration because (1) the relatively high profits of concentrated industries may allow those firms to use labor in an inefficient (in other words, $X$-efficient) manner, which may be a characteristic of employment that is attractive to workers; (2) the fewness of firms raises the probability of collusive no-raiding agreements as well as reduces alternatives for intrá-industry mobility; and (3) fringe benefits may be higher in concentrated industries. ${ }^{28}$ Parsons argues that entrance into high-concentration, high-wage industries generally requires investments by the worker, which may diminish the tendency to quit. ${ }^{29}$

These concentration-turnover findings came from regression models of the form

$$
Q R=\beta_{0}+\beta_{1} W+\beta_{2} A+\beta_{3} Z,
$$

where $Q R$ is the industry quit rate, $W$ is the current wage, $A$ represents alternative job possibilities, and $Z$ is a vector of other deter-

are overpaid relative to private sector employees, in "Are Government Workers Overpaid? Alternative Evidence," Joumal of Human Resources, Vol. 17, No. 1 (Winter 1982), pp. 123-31.

${ }^{27}$ Hendricks, "Regulation and Labor Earnings," p. 492; Ehrenberg, The Regulatory Process and Labor Eamings, pp. $108-110$.

${ }^{28}$ John F. Burton and John E. Parker, "Interindustry Variations in Voluntary Labor Mobility," Industrial and Labor Relations Review, Vol. 22, No. 2 (January 1969), pp. $199-216$.

29Donald O. Parsons, "Specific Human Capital: An Application to Quit Rates and Layoff Rates," Journal of Political Economy, Vol. 80, No. 5 (November/ December 1972), pp. 1120-43. 
minants of the quit rate (such as pensions, race, gender, and concentration). This specification can be criticized on two grounds. First, using industry aggregates as the units of observation introduces a simultaneous-equation bias because it is ambiguous whether Equation 2 is a supply or demand relationship. ${ }^{30} \mathrm{~W}$ ith individual workers as the unit of observation, however, Equation 2 can be treated as a supply relationship, because the compensation levels facing individual workers are exogenous to them. A second statistical problem is the inclusion of wages as an explanatory variable. Flanagan argues that this introduces multicollinearity (since wages may be related to race, gender, concentration, and other explanatory variables) and a simultaneity problem (employers may pay lower wages to workers more likely to quit, for example). ${ }^{31}$

With these problems in mind, we estimate the relationship between market structure and voluntary turnover using the following model specified by Flanagan: ${ }^{32}$

$$
Q_{i}=\beta_{0}+\beta_{1}\left(W_{i}-\bar{W}\right)+\beta_{2} Z_{i}
$$

where $Q_{i}$ is the quit behavior of the individual, $W_{i}$ is the individual's current wage, $\bar{W}$ is the mean market wage for workers with similar human capital and wage-related characteristics, and $Z_{i}$ contains other determinants of quit behavior. The probability of quitting the current employer is assumed, other things equal, to increase as the difference between the actual current wage and the "potential" market wage (hereafter, RESID) decreases. For our analysis, the vector $Z$ includes dummy variables indicating whether the current employer is in a regulated industry ( $R E G, M A X, M I N$, or $V A R)$; the concentration ratio $(C)$ in the individual's current (three-digit census) industry; unionization (UNION) in the

\footnotetext{
${ }^{30}$ For further discussion, see Schiller and Weiss, "The Impact of Private Pensions on Firm Attachment," p. 379.

${ }^{31}$ Robert J. Flanagan, "Discrimination Theory, Labor Turnover, and Racial Unemployment Differentials," Journal of Human Resources, Vol. 13, No. 2 (Spring 1978), pp. 187- 207.

32Ibid.
}

current industry; years of work experience with the current employer (TENURE); and dummy variables for married with spouse present (MSP) and race (WHITE). If high concentration and regulation generate positive (negative) economic rents, the coefficients of $C$ and the regulation variables are expected to be negative (positive) and statistically significant. Since the effects of concentration and regulation on the current wage will be held constant by the RESID term, negative coefficients on the market-structure variables will indicate that concentration and regulation raise nonwage compensation. From previous studies, we expect the quit probability to vary inversely with TENURE, MSP, and UNION and directly with WHITE.

Turnover data for individual workers and for the explanatory variables required to estimate Equation 3 were obtained from the National Longitudinal Surveys (NLS) of middle-aged men (aged forty-five to fiftynine). ${ }^{33}$ In the NLS, individuals are asked to compare their employers at two consecutive survey dates and to indicate whether any change in employers is due to a voluntary quit or to layoff or dismissal. In the sample of middle-aged males, comparison data on employers are reported for the years $1966-67,1967-69,1969-71$, and 197173. Labor turnover can thus be measured as a binary variable taking a value of one if a worker quits his or her job in one year and has a different employer in a later year, and taking value of zero if that worker does not change or involuntarily changes employers. Combining data for the four intervals provides a sample of 4,408 observations, including 177 instances of job quitting.

The variable RESID is calculated by subtracting individual workers" "potential" (predicted) wage from their actual wage at the beginning of a time interval. The predicted wage is based on the coefficients from a market wage equation, using the natural logarithm of the hourly wage as the dependent variable and including the following explanatory variables: years of

${ }^{39}$ Data sources for the concentration and unionization variables may be found in footnotes 10 and 11 above. 
schooling; tenure and its square; unionization; months of job-related training; and dummy variables for health, marital status, race, and geographic region. Since the turnover observations are pooled by time intervals, four separate wage equations are estimated. The wage equation samples are restricted to private wage and salary employees in manufacturing and regulated industries.

Our estimates of the impact of market structure on voluntary turnover are reported in Table $3 .{ }^{34}$ Since the dependent variable is dichotomous, the quit equations are estimated with probit analysis. The coefficient of concentration is negative and highly significant in both equations, indicating that the probability of quitting decreases as concentration rises. In contrast, the coefficients of regulation (REG) are positive, which indicates that individuals employed in regulated industries are more likely to voluntarily change employers than workers in unregulated manufacturing. Equation 2 reveals, however, that the positive impact of regulation on turnover is statistically significant only for $M A X-$ and $V A R$-type regulation.

The coefficients of the remaining variables carry the predicted signs, and RESID, TENURE, and UNION are highly significant. Since including $R E S I D$ in the quit equation holds constant any "wage differential" incentive for changing employers, the negative coefficient of $C$ in Table 3 suggests that quitting decreases as concentration rises because nonwage compensation is greater in highly concentrated industries than in competitive industries. This finding is consistent with the estimates in Table 2 , which indicate that employer expenditures on pensions and insurance increase with concentration. The results in Tables 2 and 3 suggest that workers in $V A R$-regula-

\footnotetext{
${ }^{34}$ To determine whether our estimates are biased by pooling different time intervals, we included the national rate of unemployment during the first year of each interval as a crude measure of labor market conditions. This variable was never statistically significant and its inclusion had no effect on the market structure coefficients; it was therefore dropped from the equation.
}

Table 3. Probit Analyses of the Effect of Concentration and Regulation on Voluntary Labor Turnover, 1966- 73.

(asymptotic $t$-values in parentheses)

\begin{tabular}{|c|c|c|}
\hline Variables & Equation 1 & Equation 2 \\
\hline $\mathrm{C}$ & $\begin{array}{l}-.0068^{* *} \\
(-3.13)\end{array}$ & $\begin{array}{l}-.0111^{* *} \\
(-3.64)\end{array}$ \\
\hline REG & $\begin{array}{l}.3337^{* *} \\
(3.11)^{-1}\end{array}$ & - \\
\hline MAX & - & $\begin{array}{l}.7398^{* *} \\
(2.57)\end{array}$ \\
\hline MIN & - & $\begin{array}{l}.0721 \\
(.42)\end{array}$ \\
\hline VAR & - & $\begin{array}{l}.5687^{* *} \\
(3.37)\end{array}$ \\
\hline RESID & $\begin{array}{l}-.2014^{*} \\
(-2.10)\end{array}$ & $\begin{array}{l}-.1785 \\
(-1.83)\end{array}$ \\
\hline TENURE & $\begin{array}{l}-.0489 * * \\
(-10.64)\end{array}$ & $\begin{array}{l}-.0493^{* * *} \\
(-10.64)\end{array}$ \\
\hline UNION & $\begin{array}{l}-.0059^{* *} \\
(-2.67)\end{array}$ & $\begin{array}{l}-.0048^{*} \\
(-2.06)\end{array}$ \\
\hline MSP & $\begin{array}{c}-.1484 \\
(-1.24)\end{array}$ & $\begin{array}{l}-.1545 \\
(-1.24)\end{array}$ \\
\hline WHITE & $\begin{array}{c}.0973 \\
(1.13)\end{array}$ & $\begin{array}{l}.1250 \\
(1.43)\end{array}$ \\
\hline Constant & $\begin{array}{l}-.4761^{* *} \\
(-2.74)\end{array}$ & $\begin{array}{l}-.3767^{*} \\
(-2.08)\end{array}$ \\
\hline $\begin{array}{l}-2 \times \log \\
\text { likelihood } \\
\text { ratio }\end{array}$ & 231.36 & 235.95 \\
\hline $\mathbf{N}$ & 4408 & 4408 \\
\hline
\end{tabular}

* Significant at the .05 level in a two-tailed test. **Significant at the .01 level in a two-tailed test.

tion industries are relatively more likely to quit because they receive lower fringe benefits than comparable workers in other regulated industries and manufacturing. The insignificance of the MIN terms in Tables 2 and 3 implies that setting minimum prices and restricting market entry raises wages but does not affect other kinds of labor compensation. The coefficients of $M A X$ suggest that regulation in the utility industries reduces certain kinds of nonwage compensation (other than pension and insurance 
payments) and, other things equal, results in higher labor turnover. ${ }^{35}$

\section{Summary and Implications}

Previous studies of the effect of concentration and industry regulation on labor compensation have focused predominantly on wages or earnings while ignoring fringe benefits and other kinds of nonwage compensation. Consequently, the implications of those studies regarding the impact of market structure on total labor earnings must be considered tentative. In this study, we have empirically examined the effect of concentration and regulation on labor compensation by estimating the determinants of hourly wages, fringe benefits in the form of employer contributions to pension and insurance plans, and voluntary labor turnover. The regression results reveal a positive and highly significant relationship between concentration and both wages and fringes, and a significant negative relationship between concentration and job quitting. These findings are highly consistent with the hypothesis that, other things equal, labor compensation is relatively higher in concentrated industries than in more competitive ones. Thus, it is rather ironic that certain members of Congress with close ties to organized labor, notably Senator Edward M. Kennedy, have supported legislation intended to reduce industrial concentration in the United States. ${ }^{36}$

\footnotetext{
${ }^{35}$ These kinds of nonwage compensation could include vacation and sick-leave pay, bonuses, overtime premiums, contributions to savings plans, holiday funds, employee education funds, job security, and job satisfaction. For information on the various kinds of fringe benefits, see Chamber of Commerce of the United States, Employee Benefits 1980; and Freeman, "The Effect of Unionism on Fringe Benefits." Freeman's data (p. 496) indicate that employer contributions for pensions and insurance make up only about 36 percent of measurable voluntary fringe benefits.

${ }^{36}$ Opening statement of Edward M. Kennedy in U.S. Congress, Senate, Committee on the Judiciary, Mergers and Economic Concentration, Part 1, Hearings before the Subcommittee on Antitrust, Monopoly, and Business Rights (Washington, D.C.: GPO, 1979). For additional discussion, see A. F. Ehrbar, "Bigness
}

Industry regulations that set minimum prices and restrict market entry, as in airlines and trucking, are estimated to raise labor compensation by means of increasing hourly wages. This result implies that the opposition to deregulation on the part of the Air Line Pilots Association and the Teamsters has been well founded. The relatively higher incidence of job quitting among workers in the utility industries (telephone, electricity, gas, and water) suggests that profit regulation through the imposition of maximum prices reduces labor compensation. Stronger evidence that certain kinds of regulation may decrease labor earnings is contained in the finding that in the remaining regulated industries, both wages and fringe benefits are relatively lower, whereas voluntary labor turnover is relatively higher.

The implications of this study for public policies designed to deconcentrate or deregulate industries depend on two issues. First, has labor quality adequately been held constant in the empirical analyses, so that compensation differentials reflect economic rent rather than payment for some productivity factor? Second, do the empirical findings for mature men apply to other groups of workers as well? If we assume that the relatively higher labor compensation in concentrated and $M I N$-regulated industries constitutes economic rent enjoyed by the average worker in those industries, then our findings imply that deconcentration and deregulation would reduce unit costs and lead to more efficient resource allocation throughout the economy. The income losses (reduced wages or fringes) incurred by the workers now employed in the affected industries would be more than offset by gains to consumers and other workers.

The assumption that relatively higher labor compensation (or profits) represents economic rent seems more valid in the case of industries in which entry has been artificially restricted by regulation than in

Becomes the Target of the Trustbusters," Fortune, Vol. 99, No. 6 (March 26, 1979), pp. 34-39. 
highly concentrated, unregulated manufacturing. Studies by Brozen, Demsetz, and others suggest that the relatively high profit rates in concentrated manufacturing industries reflect the greater efficiency and technological advancement of dominant firms. ${ }^{37}$ Kendrick and Grossman find that the slowdown in manufacturing productivity growth since the mid-1960s is sig-

"Y7ale Brozen, "The Significance of Profit Data for Antitrust Policy," in J. Fred Weston and Sam Peltz. man, eds., Public Policy Toward Mergers (Pacific Palisades, Calif: Goodyear, 1969), pp. 110-27; Harold Demsetz, The Market Concentration Doctrine (Washington, D.C.: American Enterprise Institute, 1973). nificantly less in more concentrated industries. $^{38}$ The relatively higher wages and fringe benefits observed in concentrated industries may thus be compensation for the higher skill levels of workers. Finally, to the extent that labor turnover raises costs and retards productivity growth, the finding that concentration reduces job quitting is certainly not supportive of public policies to reduce industrial concentration.

${ }^{38}$ John W. Kendrick and Elliot S. Grossman, Productivity in the United States: Trends and Cycles (Baltimore, Md:: Johns Hopkins University Press, 1980), pp. $106-11$. 
Copyright of Industrial \& Labor Relations Review is the property of Cornell University. The copyright in an individual article may be maintained by the author in certain cases. Content may not be copied or emailed to multiple sites or posted to a listserv without the copyright holder's express written permission. However, users may print, download, or email articles for individual use. 